\title{
Influence of Working Relationship between Principals and Teachers on Students Activities in Secondary Schools in Awgu Education Zone of Enugu State
}

\author{
Ikenga, N. C. (Ph.D) \\ Department of Educational Foundations, Faculty of Education, Ebonyi State University, Abakaliki, Nigeria \\ Ogbaga Emmanuel (Ph.D) \\ Department of Science Education, Faculty of Education, Ebonyi State University, Abakaliki, Nigeria
}

\begin{abstract}
This study investigated the Influence of Working Relationship between Principals and Teachers on Students Activities in Secondary Schools in Awgu Education Zone of Enugu State. Three research questions guided the study. Descriptive survey research design was adopted for the study. The population of the study comprised 54 principals and 785 teachers in the public secondary schools in the zone. Purposive sampling technique was employed to draw 28 principals and 252 teachers from 28 non-proportionately selected schools in the zone. A structured questionnaire in three clusters (A-C) containing 25 items titled Principal and Teachers Working Relationship on Students Academic Performance Questionnaire (PTWRSAPQ) was used for data collection. Three experts in Administration and Planning, Department of Educational Foundations and 2 experts from Measurement and Evaluation Unit, Department of Science Education both from Ebonyi State University, Abakaliki validated the instrument. Cronbach alpha was used to test the reliability of the instrument and the whole 25 items returned a coefficient of 0.61 . Data collected were analyzed using mean (X) and standard deviation (SD) to answer the research questions. The findings of the study revealed that the mean responses of principals and teachers on the influence of their working relationship on students' performance in classroom activities was no significant, the mean responses of principals and teachers based on location on the influence of their working relationship on students' performance in external examinations was not significantly different, and the mean responses of the principals and teachers based on gender on the influence of their working relationship on students' performance in internal examinations was not significantly different. Based on the findings of the study, it was recommended among others that the principals should adopt leadership styles that will foster good working relationship between them and the teachers so that the objectives of the school can be meaningfully achieved. Secondly, workshops/seminars should be organized by the government to sensitize the principals and other staff of the schools on the importance of working as team in the actualization of the goals and objectives of secondary school education.
\end{abstract}

DOI: $10.7176 / \mathrm{JEP} / 12-36-08$

Publication date: December $31^{\text {st }} 2021$

\section{INTRODUCTION}

\section{Background to the Study}

Generally, the way people relate with each other in any field of life influences the productivity, standard, quality or outcome of their endeavors. In the education sector therefore, the working relationship between principals and teachers influences students' academic performances in one way or the other. Ocho (2008) observed that education is a social activity that enhances people's relationship in order to achieve stated objectives. It is on this ground that the Federal Republic of Nigeria (2013) in her National Policy on Education, emphasizes that education is a veritable tool for the socio-economic and political development of a nation hence she refers to it as an instrument par excellence for effective national development.

It is on this basis that one will understand that the unquantifiable values attached to education can therefore account for the reason why national organizations and even private individuals spend huge sums of money, human and material resources on the provisions of qualitative education for the citizens (Ocho, 2008). Nwite (2010) argued that one widely held aim of education is to equip the individuals with the knowledge, skill, attitude and competences that enable them to render useful services to themselves and the society at large. He viewed education therefore as an indispensable catalyst that strongly influences the development and economic fortunes of every nation and the quality of life of her citizens.

In the present dispensation, parents and even guardians are becoming more cautious about the kind of education given to their children and wards as regard to their poor academic performance. Quite often, they showed their concern by demanding that the school should improve on various teaching techniques and approaches to justify their increased spending in the education of their children. The governments and international organizations are not left out either, as principals and educational administrators are often called upon to account for the huge 
investment to the sector (Modebelu and Onyali 2010). This view therefore agreed with Okwu (2007) who argued that if quality of education is to be guaranteed in schools and improved standard of education generally, good working relationship between principals and teachers should be accorded high priority.

Principal-teacher relationship is a term that is used to describe how principals and teachers in a school relate with one another in carrying out their designated roles. According to Weilson, Camborie and Wyeth (1992:131), "principal-teacher relationship is an articulating and integrating principle of action in which school staff experiment with a series of schemes, methodological strategies and peer-knowledge with which to solve educational problems". Principal-teacher relationship can be seen as an integral part of the school administrative process. In this sense, the existence of good working relations between principals and teachers becomes important. Okonkwo (2005), stated that it is when a good relationship exists between principals and teachers that they can begin to talk about their work and practice. The focus of principal-teacher working relationship is on how they relate and how it influences students' academic performance. Rutter, Mortimer and Smith in Chukwukelu (2007) posited that to improve students' performances, principals and teachers should have cordial relationship and as such, should exhibit instructional leadership that allows for team spirit in the school. Failure of principals and teachers to carry out their tasks effectively and efficiently will affect the tone of the school and academic performance of students (Chukwukelu, 2007). In the discharge of these tasks, the principal is expected to plan, control, organize, coordinate and direct human and non-human resources in the school in order to achieve the goals of the school which academic performance of the student is inclusive.

It has been noted that good working relationship between principals and teachers play a crucial and critical role in educational goal attainment because the principals and teachers are responsible for implementing policies based on practice and showing good examples during interaction with the students. Chukwukelu (2007) observed that one of the relevant factors influencing the students' learning include principal and teacher rapport because they stand in the interface of the transmission of knowledge, values and skills in the learning process. If principals and teachers are ineffective and are not performing as expected, the students under their care may likely not achieve enough progress academically.

Through observation as a professional teacher, the researcher noted that lack of cordial relationship between principals and teachers may significantly contribute to low academic performance of the students. In the same vein, the inability of teachers to complete the syllabus, set standard questions during examination that will cover cognitive, affective and psychomotor domains or give out relevant projects or take home assignments to students, collect and create time to mark and assess them and finally give corrections to students which could be regulated by the principals through their oversight functions will obviously affect students academic performance adversely. It is of truth that teaching and learning will not be functional if principals and teachers are having gap in communication, or good rapport. That is why it is necessary for principals to be motivating their teachers to enable them to be more dedicated to their work and to carry out their routine work effectively and efficiently with happiness. Oredein and Oloyede (2007) maintained that teacher management of home work and assignments given to students have an impact on students' achievement especially when it is well explained, corrected and reviewed during class time and used as an occasion for feedback to students.

Good working relationship, if it exists between principals and teachers is very vital in the school system. Principal-teacher good working relationship is important because, it will ensure that laid down standards and maintained and the objectives of the school pursued to a meaning end. It will also create a friend atmosphere that will motivate students to learn. Chukwukelu (2007) maintained that principal- teachers' co-operation while on duty in schools is complex and intertwined. In almost all school activities, good relationships help to play an important role. Working days for principals and teachers contain many meetings, interactions and conversations. And when such are functioning effectively, may contribute largely to school outcomes especially on students' academic performance. Principals need to have or acquire features of leadership to enable them carry their teachers along. One of the principals' challenges is to support teachers to improve students' outcome. What principals and teachers talk about and how they relate influence and reflect on students' academic performance. As a good leader who wishes to maintain good working relationship with her teachers by working harmoniously with them in order to achieve students' academic performance he/she should possess some outstanding leadership qualities which involve rational thinking ability, thinking critically and arriving at a logical conclusion (Germain, 2006).

The term academic performance has been described as the scholastic standing of a student at a given moment. It refers to how an individual is able to demonstrate his or her intellectual abilities. This scholastic standing could be explained as the grades obtained in a course or groups of courses taken (Chukwukelu (2007) and Simikens (1981) commented on the scholastic standing of students and argued that performance is a measure of output and that the main outputs in education are expressed in term of learning. That is, changes in knowledge, skills and attitudes of individuals as a result of their experience within the school's system. Thus, in determining academic performance, Oredein and Oloyede (2007) emphasized the use of grades in examinations as prediction measures and as criterion measure for reporting and placement. Good academic performance therefore, is largely identified by a range of statistical indicators. Stan (2007) supports this argument and reported that performance is the level 
of attainment of a person in an examination; that is the grade of an individual in a test or examination. Similarly, Adeyemi (2006) saw academic performance as a measure of educational output. It is against this backdrop that Oguntoye (2000) argued that performance of students in public examinations in many Nigerian schools has been poor as academic performance over the years showed. Much work is expected from the principals and teachers in order to improve the level of academic performance of students in secondary schools especially in Enugu state.

One question, that has preoccupied researchers for decades is why do particular students perform well in examinations and others consistently perform poorly? A number of researchers including Edmonds , Egboka (2004), Lezotte, Skaife and Holstead (2002), Kirk and Jones (2004) and Daggett (2005) have demonstrated that successful schools that have unique characteristics and processes which help all children to learn at high levels make them achieve better academically. Many studies carried out to determine what accounts for improved academic outcomes, have shown it is mostly based on quality of teachers or basic infrastructural materials. Academic performance is a key concern for educational researchers, because failure in national examination spells doom for the students whose life become uncertain and full of despair. Academic performance determines whether the student will proceed to university or to other tertiary institutions. Therefore, students' life may be determined by his or her academic performance in the national examinations. Hence, the need for principals and teachers to work harmoniously to building the students toward improved performances in examinations (internal and external) cannot be over emphasized.

The National Examination Council (NECO) who conducts Senior Secondary School Certificate Examination (SSCE) in Nigeria decries the poor level of performance of students in the subjects they have learnt in school. Okeke (2005), stated that this examination is used to assess the worth of students' learning as well as to predict how well the students will do in future academic endeavours. In Enugu state, parents, educators and the general public are concerned about students' academic performance in secondary schools. Okeke (2005) in a related study carried out in Abia state found out that students have continued to perform poorly in internal and external examinations in core subjects especially English Language and Mathematics. Udoezike (2006) stated that the academic performance of Secondary school students in Enugu State is on the decline going by the results of the external examination conducted by the West African Examination Council (WAEC). The consequences of low performance are that the goals of secondary education are far from being achieved. Teachers are therefore, being challenged to make efforts to raise the academic performance of students.

In examining the characteristics of schools that have made gains, researchers have tried to verify whether the quality of the relationship with a school community make a difference (Young, Hoy and Tschannem, 2003). Sebring and Bryk (2000) stated that in secondary schools, where trust, co-operation and good relationships are strong, students report that they experience greater academic achievements. However, it is noticeably clear that in schools with flat or declining test scores, teachers are more likely to state that they do not trust one another because cordial relationships do not exist. The effect of working relationships among teachers and principals in particular have been identified as important indicators of a schools' readiness for improvement and the ability to sustain it. Good working relationship between principals and teachers helps in carrying out their work mutually and therefore influences students' learning outcome positively.

The United States Department of Education (2003) Comprehensive School Reform Programme (CSR), for example, emphasized that if improvement efforts are to be successful over long term, such principal must first build a solid foundation for school wide report. Such foundations as noted by Keirstead (1995) and Hale (2000) are characterized by trust among school members, collegiate relationships and wide spread support, as well as a shared vision for collective goal. Good-Lad (1998) pointed out that much of what happen in schools including how students learn and react are influenced either positively or negatively by the nature of principal-teacher relationships that exist in schools. Good working relationship if it is in existence in school is important because some teachers have personal problems that require assistance from the principals. Ademola (1999) noted that some principals are known to go extra miles to lessen the distress of some of the teachers either from the family side, accommodation side, or financial reasons. At times, some principals do give listening ears to the problems of the teachers and offer useful advice and assistance. But some seem not to care. They see their teachers only in terms of whether or not they perform their teaching assignments. The welfare of the teachers is considered as relevant, thus, it appears that some Nigerian teachers receive sufficient encouragement, which they need to live up to expectation and others do not. This also applies to principals, some of them have problems that need teachers' involvement as part of the solution, but such will not yield a reasonable result because of the distance in their relationship and without good rapport. Some teachers complain a lot about their principals and will never discuss matters with them through cordial dialogue. While they may supply useful information for effective running of the school, they can also destroy the fabric and the foundations of the institution. Based on this conflict weather, such can equally lead to continual negligence of duties by the teachers. All these are likely to influence the type of relationship existing between principals and teachers and consequently may hinder students' academic performance.

Besides, it is expected that where good principals and teachers' relationship exists in schools, principals and 
teachers may work more effectively and efficiently. Bello (2004), stated that good principal and teacher relationship foster the teacher's ability to teach what he is expected at any particular time and participate in school extra-curricular activities. Blasé (2001) noted that good principal and teacher relationship influences the teacher's classroom task performance in terms of the extent to which a teacher is judicious in preparing his/her lesson notes, keeping his or her classroom in order, disciplining his students' learning outcome. These activities are necessary for the improvements of students' academic performances. If principal and teacher relationship hinders teacher's task performance, then, it may influence students' academic performance especially in core subjects like English and Mathematics and other subjects negatively and such will limit students' learning. English Language and Mathematics are among the subjects made compulsory for all secondary school students. A strong background in English Language and Mathematics is crucial for many careers and job opportunities in today's increasing technological society. According to Amoo and Efunbajo (2003), no other subject has greater application in education than English Language and Mathematics. The importance attached to performance in English Language and Mathematics is such that at least credit level in both with other three subjects are required for admission into most universities in Nigeria, making it important that students should strive to record high achievement scores in the subjects. It is therefore, a matter of serious concern when students perform poorly in these important subjects. The ineffectiveness of some teachers in classroom interaction with the students can be responsible for the poor performance of students as well as the widely acclaimed failure of teachers in their duty to complete their scheme of work, teach students well and give them necessary corrections which invariably may deprive the students from measuring up well in their academic performance.

Poor academic performance of students in both internal and external examinations may be linked to poor working relationship between the principals and the teachers in terms of accomplishing the teaching task, negative attitude to work and poor teaching habit which may result to poor motivation (Ofoegbu, 2004).

Co-curricular activities according to Fuhraman and Malen (2000) is not teaching and learning in the classroom but includes work in library, laboratory and workshop, participation in games and sports in playground, debates, quiz and numerous informal contacts between teachers and students. Actually, "all work and no play make Jack a dull boy" and this type of activity may elevate students to be physically and spiritually healthy and may equally enable them to face their academic work effectively by being more agile and active. Co-curricular activities previously recognized as extra-curricular activities serve the same purpose of enhancing social activities in the school. These school activities which could be measured through continuous assessment in the school system will function well if there is positive relationship between principal and teachers. According to Falayalo (1986) continuous assessment of students' progress can be defined as a mechanism whereby the final grading of learners in the cognitive, affective and psychomotor domains of learning systematically take account of all their performances during a given period of schooling. Assessment in the cognitive domain is associated with the process of knowledge and understanding. The affective domain applies to characteristics such as attitude, motives, interests and other personality traits; assessment in psychomotor domain involves assessing the student' ability to use his or her hand (for example in hand writing, construction and projects). Airasian (1991) described

Continuous assessment as an approach which should depict the full range of sources and methods teachers used to gather, interpret and synthesize information about students, information that will help teachers understand their students' plan and monitor instruction and establish a viable classroom culture. Baker and Stites (1991) opine that continuous assessment should involve a formal assessment of students' affective characteristics and motivation in which they need to demonstrate their commitment and their competence in team or group performance context. According to Lewis (1997), with continuous assessment, teachers will remember the assessment in their instructions; score the assessment and discuss standard for good students' work with colleagues, parents or students. Continuous assessment involves record keeping and whereby there is no cordial relationship between the principal and teachers such record keeping may not be carried out effectively and as a result, it will spell more on the academic performance of the students.

Regular attendance to school is one of the most important things a students can do to achieve academic success. Students who attend school regularly will more likely pass reading and mathematics assessments than students who did not attend school regularly (Cone and Foster 1991). Regular attendance to school from personal observation as a professional teacher will help a students to build a successful academic record. Then who will keep this record? Whereby the working relationship of principals and teachers are like cat and dog'. Such function may not be carried out effectively because of lack of good human relationship between the school principal and teachers. Whereby two elephants fight, the grasses will suffer and definitely, students' academic performance may decline. The next other question is determining however, the nature, kinds and possible gains from this good relationship and interaction between either male, female teachers and or principals, either in the rural and or the urban/semi urban areas of Awgu Education zone. It is of interest too to determine whether this relationship could be enhanced based on the teachers' training, age or working experiences. All the aforementioned measures are designed to enthrone peaceful and fruitful working relationship among the school community, as well as enhance better academic performances among the students. 
Baker (2006) notes that assigning projects to students is the most pragmatic ways of helping students to acquire skills because students because of the processes involved before its fruition begins to manifest. In addition to utilizing strategies such as backward design, goal setting and implementing an effective process, project skills develop character and fortitude in students for their future career; but who will supervise this for better academic performance of the students except if there is cordial relationship between principals and teachers. In the school system, it is the responsibility of the school principals or the administrators to maintain staff competence. In Nigeria for instance, internal supervision of students' performance is mostly performed by the school heads or principals who are saddled with the responsibility of classroom visitation in order to watch teachers and student in action (Nwite, 2010).

Against these backdrops, the researcher therefore decides to investigate on the influence of working relationship between principals and teachers on the students' academic performance in secondary schools in Awgu Education Zone of Enugu state.

\section{Statement of the Problem}

Issues relating to quality assurance, principals and teachers effectiveness and students' academic performance are gaining serious attention in the education agenda especially in developing countries like Nigeria. The persistent drop in the academic achievement of students in recent times in Nigeria as reported by various examination bodies like WAEC and NECO with particular reference to Enugu state has continued to raise gross concern among stake holders who have continued to watch helplessly the progressive decline in the quality of secondary school leavers or graduates. Actually, there have been some growing trends in the poor academic performance of secondary school students because their performance is no longer impressive.

Researchers have continued to investigate the causes or reasons behind this ugly menace, so as to alleviate the educational sector from its present situation. Some educators have sometimes blamed the condition on the continuous neglect of school heads and teachers which often result to incessant industrial actions; while others argued that poor funding of the educational sector, emphasis on certificate, increase cases of truancy among students, poor principal-teacher working relationship and students-teachers relationship as the brain behind the menace.

In Enugu state, the existence of a good working relationship between principals and teachers at secondary school level appears questionable as there are noticeable cases of unacceptable behavior like conflicts which is very common in some schools resulting from teachers' non-compliance with principals directives. Equally, principals' indifference to teachers' needs, teachers laxity toward class work, teacher inability to complete his/her scheme of work because of lack of motivation from the principals side, teachers quarrel against teachers, and the fact that some teachers even fight their principals, are also source of poor academic performance by students. Also, some teachers because of the disparity in school make them to form cliques- Some belong to principals party and others belong to opposition party trying their possible best to water the administration of the principal from grace to grass. In the same, some because of bickering and antagonistic nature of the principal will be scaring them away from being regular to school, instead they will be absent from school and may engage themselves into a personal business in search of comfort and happiness. It is on the above premise that the problem of this study may be posed in a question form thus; how does the working relationship between principals and teachers influence students academic performance in secondary schools?

\section{objective of the Study}

The general purpose of this study was to examine the influence of working relationship between teachers and principals on students' activities in secondary schools. Specifically, the study sought to:

1. determine the influence of principal-teacher relationship on students academic performances in classroom activities;

2. ascertain the influence of principal-teacher relationship on students academic performances in internal examinations;

3. find out the influence of principal-teacher relationship on students' academic performances in external examinations;

\section{Research Questions}

The following five research questions have been formulated to guide the study.

1. What is the influence of working relationship between principals and teachers on students' academic performances in classroom activities?

2. What is the influence of working relationship between principals and teachers on students' academic performances in internal examinations?

3. What is the influence of working relationship between principals and teachers on students' academic performances in external examinations? 


\section{METHODS AND MATERIALS \\ Research Design}

The research design selected for this study was a survey design. According to Abonyi, Okereke, Omebe and Anugwo (2006), descriptive survey consist of those studies in which data are collected from a small sample of a large population to enable the researcher describe in a systematic manner and interpret the characteristic features and facts about things that exist. The study was conducted in Awgu Enugu State. Awgu Education Zone is made up of three (3) Local Government Areas namely; Aninri, Awgu and Oji-River Local Government Areas. The researcher decided to carry out this study in Awgu Education Zone to ascertain the influence of working relationship between principals and teachers on students' academic performance The population of this study comprised all the 54 principals and 785 teachers' from all the 54 public Secondary Schools within the area of this study. In all, there exist a total number of 54 principals and 785 teachers in public secondary schools in the area (Post Primary School Management Board (PPSMB, Enugu, 2015). One hundred and eighty (180) teachers in Aninri Local Government Area, 361 teachers in Awgu Local Government and 244 teachers in Oji-River Local Government Area. The population of this study therefore stand to 839. 280 were sampled for the study which was obtained through non-proportionate stratified random sampling. The researcher developed a structured questionnaire instrument titled "Principal-Teacher Working Relationship on Students' Academic Performance Questionnaire (PTWRSAPQ)" and was used for data collection of this study. The instrument was validated by five experts, three experts from Educational Administration and Planning Unit, Department of Educational Foundations and two experts from Measurement and Evaluation Unit, Department of Science Education, Ebonyi State University, Abakaliki respectively. The validators assessed the instrument in terms of the wordings, sentence structures and the instrument structures in eliciting the appropriate data from the respondents for the study. Their suggestions and recommendations which majored on the wording and sentence restructuring of the items were effected before drafting the final copy that was used for data collection of this study. The validated copy of the instrument was pilot tested using 15 principals and 15 teachers from schools in Enugu Education zone of Enugu state. Their responses were subjected to reliability test using Cronbach Procedure Alpha and the whole 37 items of the instrument returned a reliability coefficient of 0.61 . Based on clusters, cluster A had a reliability coefficient of 0.67 , cluster B had a coefficient of 0.64 , cluster $\mathrm{C}$ had a coefficient of 0.59 .

The researcher personally visited the sampled schools, and administered the instrument to the respondents and collected back the filled instruments at the spot from the respondents. The researcher did this to avoid loss of the questionnaire or some of the questionnaire not being returned. The researcher used descriptive statistics of mean and standard deviation to answer the research questions and inferential statistics of t-test to test the hypotheses. The hypotheses were tested at 0.05 alpha level of significance. A mean score of 2.50 and above were accepted, while a mean score less than 2.50 were rejected. Also, if the t-calculated value is greater than the $t$ critical value, the null hypothesis was rejected and vice versa. Findings of the study revealed as follows:

Research Question 1: What was the influence of working relationship between principals and teachers on students' academic performance in classroom activities?

Table 1: Mean with standard deviation of principals and teachers on the influence of principal-teacher working relationship on students' academic performance in classroom activities.

\begin{tabular}{llccc}
\hline S/N & \multicolumn{1}{c}{ Items } & X & SD & Interpretation \\
\hline 1 & Orderliness of classroom & 3.25 & 0.98 & Agree \\
2 & Use of relevant instructional materials & 3.04 & 0.98 & Agree \\
3 & Regular attendance to class & 2.96 & 1.03 & Agree \\
4 & Availability of textbooks for lessons & 2.96 & 1.01 & Agree \\
5 & Good use of continuous assessment & 2.85 & 1.04 & Agree \\
6 & Application of good teaching methods & 2.97 & 0.97 & Agree \\
7 & Attentiveness during lesson & 2.84 & 0.94 & Agree \\
8 & Teachers' counselling of students & 2.92 & 0.94 & Agree \\
9 & Individualized attention to learners & 2.94 & 1.00 & Agree \\
10 & Humour by teachers' for clarity during lesson & 3.17 & 0.94 & Agree \\
& Grand Mean & $\mathbf{2 . 9 9}$ & & Agree \\
\hline
\end{tabular}

The result on table 1 above reveled that all the items were accepted for having a mean value above the criterion mean value of 2.50. With a grand mean score of 2.99, it shows that the respondents agreed that good working relationship between the principals and the teachers will have positive influence on students' performance in classroom activities in secondary schools in Awgu Education Zone of Enugu State.

Research Question 2: What was the influence of working relationship between principals and teachers on students' academic performance in internal examinations? 
Table 2: Mean with standard deviation of principals and teachers on the influence of principal-teachers relationship on students' academic performance in internal examinations.

\begin{tabular}{llccc}
\hline S/N & \multicolumn{1}{c}{ Items } & $\mathbf{X}$ & $\mathbf{S D}$ & Interpretation \\
\hline 11 & Preparation for examinations & 2.95 & 1.07 & Agree \\
12 & Avoidance of anxiety for examinations & 3.08 & 0.92 & Agree \\
13 & Stress free examination conditions & 2.89 & 1.05 & Agree \\
14 & Creating conducive environment for examinations & 2.96 & 1.04 & Agree \\
15 & Correlation of continuous assessment scores & 2.94 & 1.01 & Agree \\
16 & Good arrangement of seats in examination halls & 2.88 & 1.01 & Agree \\
17 & Neatness of students during examinations & 2.89 & 1.01 & Agree \\
18 & Avoidance of examination malpractice & 2.88 & 1.02 & Agree \\
19 & Early attendance to school during examination & 2.91 & 0.96 & Agree \\
20 & Good invigilation during examination & 2.72 & 0.97 & Agree \\
& Grand Mean & $\mathbf{2 . 9 1}$ & & Agree \\
\hline
\end{tabular}

The result on table 2 indicated that all the items were accepted for having a mean score above the criterion mean value of 2.50. A grand mean score of 2.91 showed that the respondents agreed that good principal-teacher relationship will have positive influence on students' performance in internal examinations in secondary schools in Awgu Education Zone of Enugu State.

Research Question 3: What was the influence of working relationship between principals and teachers on students' academic performance in external examinations?

Table 3: Mean with standard deviation of principals and teachers on the influence of principal-teachers working relationship on students' academic performance in external examinations.

\begin{tabular}{llccc}
\hline S/N & \multicolumn{1}{c}{ Items } & $\mathbf{X}$ & SD & Interpretation \\
\hline 21 & Regular attendance to school enhances academic performance & 2.69 & 0.98 & Agree \\
22 & Habitual late coming/absenteeism build successful academic & 2.46 & 1.17 & Disagree \\
& $\begin{array}{l} \\
\text { record }\end{array}$ & 2.83 & 1.05 & Agree \\
23 & Teachers satisfaction to embark on routine duty & 2.87 & 1.07 & Agree \\
25 & Inability to administer discipline as a corrective measure & 2.85 & 1.09 & Agree \\
& Regular attendance to school stimulate academic success & $\mathbf{2 . 7 4}$ & & Agree \\
\hline
\end{tabular}

Result on table 3 showed that the respondents agreed on items 21, 23, 24 and 25 with mean scores of 2.69, $2.83,2.87$ and 2.85 respectively while they disagreed on item 22 with mean score of 2.46 . However, a grand mean score of 2.74 showed that the respondents were in agreement that good principal-teachers working relationship will enhance positively, students performance in external examinations in secondary schools in Awgu Education Zone of Enugu State.

\section{Discussion}

Influence of Principal-Teacher Working Relationship on Students' Academic Performance in Classroom Activities

Result of analysis on table 1 showed that the respondents were in agreement that good working relationship between principals and teachers in secondary schools in Awgu Education Zone of Enugu State will enhance students' academic performance in classroom activities because it will ensure that there is orderliness of classroom during lesson, use of relevant instructional materials during teaching-learning process,. In addition, good working relationship between principals and teachers will ensure that adequate textbooks for lessons, good use of continuous assessment, and application of good teaching method by the teachers and attentiveness of the students during lesson. It will also encourage the teachers to counsel the students as when necessary, make the teachers to grant individualized attention to the learners and spur teachers to exhibit humour during lesson and ensure that clarity is maintained during lesson.

\section{Influence of Principals-Teachers Working Relationship on Students' Academic Performance in Internal Examinations}

Finding of the study revealed that the respondents were in agreement that a good working relationship between principals and teachers in secondary school in Awgu Education Zone of Enugu State will enhance students' preparation for examination, make the students to handle anxiety during examination, encourage stress free examination conditions and creates conducive environment for examinations. In addition, the finding revealed that good working relationship between principals and teachers will result in appropriate correlation of /integration of students continuous assessment scores with their examination scores, ensure good arrangement of seats in examination halls, encourage students to be neat during examinations. It will also encourage the students to avoid examination malpractice, encourage early attendance to school during examination and ensure good invigilation 
exercise during examination in secondary schools in Awgu Education Zone of Enugu State.

Influence of Principals-Teachers Working Relationship on Students' Academic Performance in External Examinations

Result of the study revealed that the respondents' were in agreement that good working relationship between principals and teachers in secondary schools in Awgu Education Zone of Enugu State will encourage students to attend school regularly, results in teachers' satisfaction to embark on routine duty, ensure that the right discipline is administered to the students as and when necessary. Furthermore, cordial working relationship between principals and teachers as revealed by the findings will ensure that students attend school regularly so as to acquire the necessary knowledge incidental for them to perform well academically especially in external examinations. However, the respondents were in disagreement that habitual late coming/absenteeism to school builds successful academic record.

\section{Recommendations}

The following recommendations were made based on the findings of the study:

1. The principals should adopt leadership style that will foster understanding and good working relationship between them and the teachers to ensuring meaningful actualization of the goals and objectives of the school;

2. The principals in secondary schools within Awgu Education Zone of Enugu state should ensure that they encourage organizational skills such as team work with the staff, and various qualities of improvement measures to influence high academic performance of the schools both internally and externally.

3. Principals should endeavour to acquire the necessary managerial/leadership skills that would foster good working relationship between them and the staff of the school.

\section{Conclusions}

The conclusion drawn from this study was that positive or healthy working relationship between principals and teachers will significantly influence students' academic performance in classroom activities, internal and external examinations, co-curricular activities and continuous assessment in secondary schools in Awgu Education Zone of Enugu State. The implication is that the working relationship between the principals and teachers in the school has direct bearing on the students' performance.

\section{References}

Abonyi, O.S., Okereke, S.C., Omebe. C.A. and Anugwo, M.N. (2006). Fundamentals of educational research. Enugu: Fred-Ogah Publishers.

Ademola, L.A. (1999). Management support and the staff. Akure: Fagbanigbe Press.

Adeyemi, T.O. (2006). Research methods and thesis writing in educational studies. Lagos: New Haven Publishers. Airasian, P.W. (1991). Classroom assessment. New York: Mc Graw-Hill.

Amoo, A.S. and Efubanjo, O. (2003). An investigation into the stress encountered in the teaching of mathematics in secondary school. Proceedings of the $44^{\text {th }}$ Annual Conference of the Science Teachers Association of Nigeria. Pp 177-181. Bryk, A.S. \& Schneider, B. (2002)

Baker, E.L. (1991). Trends in testing in the United States of American in S.H. Fuhraman and B. Malen (eds.) The politics of curriculum and testing. Pp. 139-159.

Bello, C. (2004). The Nigerian teacher and nation building. Nigerian Journal of Curriculum and Instruction, 10(5), 23-26.

Blaise, J. and Blaise, J. (2001). Teachers perspective on how principals promote teaching and learning in schools. Journal of Education and Administration, 38(2), 130-141.

Bryk, A.S. and Schneider, B. (2002). Trust in schools: a core resource for improvements. New York: Rusell Sage Foundation.

Bryk, A.S. and Schneider, B. (2003). Building trusting relationship for school improvement: trust among educators. Retrieved from: http://www.nwrd/org/request/2003/sep/trust/pdf. 7th June, 2015.

Chukwuekelu, M.N. (2007). Principal-Teacher relationship and students' academic performance in secondary schools in Anambra State. Unpublished masters dissertation, Faculty of Education, Nnamdi Azikiwe University, Awka.

Egboka, P. (2004). Relationship between principal communication styles and teachers compliance with principals' directives. Unpublished . M.Ed. Project. Nnamdi Azikiwe University, Awka.

Federal Republic of Nigeria (FGN, 2013). National Policy on Education (6 $6^{\text {th }}$ edition). Lagos: Nigeria Educational Research and Development Council (NERDC).

German, M.L. (2006). What experts are not: factors identified by managers as disqualifiers for selecting subordinates for expert team membership. Academy of Human Resources Development Conference, Columbus.

Gilmmet, F.O. and Grehen, M.N. (2003). The school work environment and teacher career dissatisfaction. 
International Education Journal, 4(3), 224-230.

Goodman, S. (2000 ). Artist and educator. Oakland: California Press.

Hale, S.H. (2000). Comprehensive school reform search based strategies to achieve high standards. San Francisco, C.A: West Ed, Comprehensive Regional Assistance Center, Region X1. Retrieved June 8, 2015.

Keirstead, C.J. (1999). Readings for CRSD. CSR Briefs, 1(3), 1-4.

Kirk, D.J. and Jones, T.C. (2004). Effective schools assessment report. Sam Antonio, TX: Pearson Education.

Nwite, O. (2010). Deviant behaviour among undergraduates of Ebonyi State University. EBSU Journal of Educational Administration and Planning, 1(1), 299-309.

Obemata, J.O. (1988). Non-cognitive assessment in education evaluation. Unpublished M.Ed. thesis, University of Ibadan, Nigerian.

Ocho, L.O. (2005). Issues and concerns in education and life. University of Nigeria Nsukka: Institute for Development Studies.

Ofoegbu, F.I. (2004). Teacher Motivation: a factor for classroom effectiveness and school improvement in Nigeria. Gale group. Retrieved August 15, 2005 from http;//www.findarticles.com

Oguntoye, S. (2000). Relationship of principals leadership style and organizational climate in secondary school. Unpublished M. Ed. Thesis, University of Port Harcourt.

Okeke, J.E. (2005). The influence of miracle centres on Nigerian education standards. Paper presented at a conference on the state and future of education in Nigeria held at Federal College of Education (Technical) Abia State. $13^{\text {th }}-17^{\text {th }}$ June.

Okon, C.B. (2007). Supervising techniques for supervision: implication on teachers' competence. Educational Managers 2(1), 23-30.

Okonkwo, S. (2005). School administration variables and staff collegiability in secondary schools. Unpublished M. Ed. Thesis, Faculty of Education, Nnamdi Azikiwe University, Awka.

Okoro, E.T. (2002). Principles of effective management. Benin: Ethiope Publishers.

Okpala, P.M. (2011). Mass failure as NECO releases results. The Nation Newspaper, pp 31.

Olaleye, F.O. (2013). Principals organizational management and students academic achievement in secondary schools in Ekiti State, Nigeria. Singaporean Journal of Business Economics and Management Studies, 2(2), 76-84.

Onwadie, I. (2011). West African Senior School Certificate Examination Result.

Oredein, A.O. and Oloyede, D.O. (2007). Supervision and quality of teaching personnel effects on students academic performance. Educational Research and Review, 2(3), 32-35.

Owoyemi, N. (2000). Moderation and standardization of continuous and terminal assessment scores in junior secondary school certificate examination and primary school leaving certificate assessment paper delivered at the senior staff seminar, Ministry of Education, Ado-Ekiti, $2^{\text {nd }}$ March, 2-9.

Peretmode, V.F. (1991). Educational Administration: applied concepts and theoretical perspectives for students and practitioners. Lagos: Joja Educational Research and Publishers Limited.

Rutter, M.B. Mangham, P., Mortimer and Smith, A. (1979). Fifteen thousand hours in secondary schools and their effects on children. Cambridge, Havard University, USA.

Sebring, P.B. and Bryk, A.S. (2000). School leadership and the bottom line in Chicago. Phi Delta Kappah, 8(6), 440-443.

Simkens, T. (1981). Economics and the management of resources in education. Shefield.

Sirvani, H. (2007). The effects of teacher communication with parents on students' mathematics achievement. American Secondary Education, 36(1), 31-46.

Science Teachers Association of Nigeria (STAN, 1992). Raising the performance of students in public examinations in Science, Technology and Mathematics. paper presented at the WAEC symposium held at the University of Ibadan, Nigerian, $24^{\text {th }}$ April, pp 1-6.

Tschannem-Moran, M. (2003). Fostering organizational citizenship in schools: transformational leadership and trust. Journal of Educational Administration, 39(4), 308-331.

Udoezika, C. (2006). Relationship between staff personnel conflicts and students' academic performance in secondary schools. Unpublished M. Ed. thesis, Faculty of Education, Nnamdi Azikiwe University, Awka.

Wellson, C., Camborine, V., and Wyeth, A.C. (1992). Accountability in principal-staff relation. American Education, 23(11), 1-9. 